\title{
Ene Reaction of Nitrosocarbonyl Mesitylene with the Cinnamyl Alcohol: Metabolic Activity and Apoptosis of the Synthetized 6-Chloropurine N,O-Nucleoside Analogues
}

\author{
Misal Giuseppe Memeo, ${ }^{\dagger}$ Elena Valletta, ${ }^{\ddagger}$ Beatrice Macchi, ${ }^{\ddagger}$ Alessio Porta, ${ }^{\dagger}$ Bruna Bovio, ${ }^{\dagger}$ \\ Mattia Moiola, and Paolo Quadrelli* ${ }^{\dagger} \dagger$ (৫) \\ ${ }^{\dagger}$ Department of Chemistry, University of Pavia, Viale Taramelli 12, 27100 Pavia, Italy \\ ${ }^{\ddagger}$ Department of System Medicine, University of Rome Tor Vergata, Via Montpellier 1, 00133 Roma, Italy
}

\section{Supporting Information}

ABSTRACT: Nitrosocarbonyl mesitylene intermediate undergoes an ene reaction with cinnamyl alcohol affording the corresponding 5-hydroxy-isoxazolidine in fair yields. The synthesized 5-acetoxy-isoxazolidine serves as synthon for the preparation of 6-chloropurine $\mathrm{N}, \mathrm{O}$-nucleoside analogues, according to the Vorbrüggen reaction. The compounds were evaluated for their metabolic and apoptotic activity, and their structure-activity relationship is discussed.

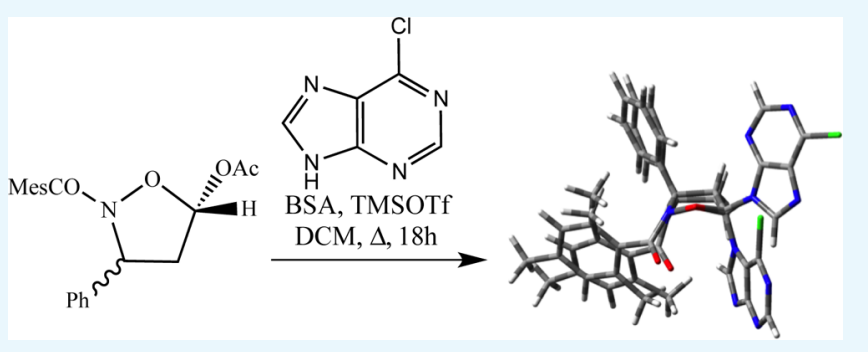

The reactions proceed straightforward to the ene adducts in accordance with the prevailing highest occupied molecular $\operatorname{orbital}_{(\text {alcohol) }}$-lowest unoccupied molecular orbital ${ }_{\text {(nitrosocarbonyl) }}$ interaction, somewhat enforced by the polarization of the $\mathrm{C}=$ $\mathrm{C}$ double bond induced by the slightly electron-withdrawing group $\mathrm{CH}_{2} \mathrm{OH}{ }^{7}$ When sterically demanding nitrosocarbonyl mesitylene $\mathbf{1} \mathbf{M}$ ( $\mathbf{M}=$ mesityl), the Markovnikov (M) directing effect is relieved and the anti-Markovnikov (AM) pathway becomes competitive and the preferred one. The selectivity drift is further increased when the bulkier anthracene nitrosocarbonyl intermediate $\mathbf{1 A}\left(\mathbf{A}=\right.$ anthryl) is used..$^{5}$ The $\mathrm{AM}$ route preludes the enol formation and the subsequent cyclization to the isoxazolidines Isoxd, which are the synthons for the preparation of libraries of N,O-nucleosides $\mathbf{N}, \mathbf{O}-\mathbf{N}$ containing uracil and purine heterobases inserted by adapting to the scope the Vorbrüggen protocol (Scheme 1).

On pursuing our research in nitrosocarbonyl ene reactions, we set up a reliable and robust methodology for the synthesis of the 5-hydroxy-isoxazolidines required for the nucleoside preparation on suitable amounts to test them for their potential biological activities and in particular to verify their metabolic and induced cell death by apoptosis.

For the scope of the present work, we selected the compounds derived from the ene reaction of the cinnamyl alcohol and the mesityl nitrosocarbonyl intermediate. The choices of the mesityl group as a substituent for the aromatic nitrosocarbonyl intermediate and of the cinnamyl alcohol as an ene partner rely upon the following considerations: (i)

Received: May 11, 2018

Accepted: June 26, 2018

Published: July 10, 2018 
Scheme 1. Ene Reaction of Nitrosocarbonyl Intermediates 1 with the 3-Methyl-2-buten-1-ol and Synthetic Pathway toward Isoxazolidine N,O-Nucleoside Analogues

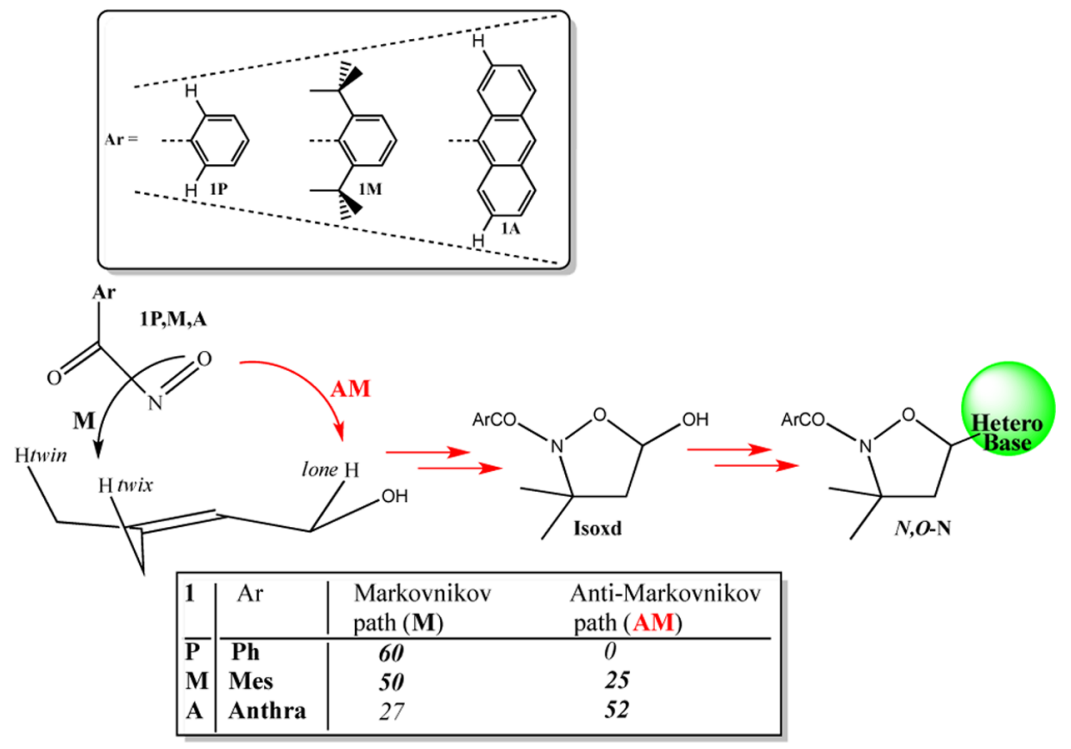

nitrosocarbonyl benzene reacts too fast not only with alkenes but also through dimerization (i.e., decomposition) and can follow competitive pathways, such as nucleophilic attack by the hydroxyl group of the allylic alcohol; on the other side, the mesityl nitrosocarbonyl reacts more slowly and is able to follow the AM reaction path required for the isoxazolidine synthesis; (ii) although the use of a disubstituted allylic alcohol may determine the activation of a competitive 1,3-dipolar cycloaddition path, the choice of the cinnamyl alcohol also relies on the fact that it has a single possibility of allylic hydrogen abstraction oriented to the formation of the isoxazolidine ring. This simplifies the ene reaction, and the introduction of the phenyl group in the position 3 of the isoxazolidine ring could help in the definition of the stereochemistry of the nucleoside analogues. Previous observations showed that some of the synthetized compounds displayed remarkable and interesting activities. The results here obtained and their interpretation allows for a structure-activity relationship (SAR) discussion, pointing out the importance of the regiochemical outcome of the heterobase functionalization of the 5-hydroxy-isoxazolidines. To do this specifically, the Vorbrüggen protocol, suitably adapted to the reagents, offers in a single reaction the possibility to insert an interesting range of heterobases.

The choice of the 6-chloropurine, as a versatile heterobase, was determined by the opportunity offered by the ease substitution of the chlorine atom with a variety of nucleophiles to investigate simple structure modifications apt to tune properly the biological activity of the stereo- and regioisomeric products, also in view of the SAR discussion.

\section{RESULTS AND DISCUSSION}

A dichloromethane (DCM solution of mesitonitrile oxide (MNO) was added to a stirred solution of $\mathrm{N}$-methylmorpholine $N$-oxide (NMO, 1.1 equiv) in DCM in the presence of an excess ( 5 equiv) of trans-cinnamyl alcohol, leaving the reaction mixture overnight at room temperature (rt) (Scheme 2). The ene adduct 4 was isolated upon chromatographic purification from the reaction mixture in $40 \%$ yield. Besides the excess of cinnamyl alcohol, the mesitoic anhydride was the major side product $(38 \%)$ isolated from the reaction mixture as a result of
Scheme 2. Ene Reactions of Nitrosocarbonyl Mesitylene Intermediate with the trans-Cinnamyl Alcohol

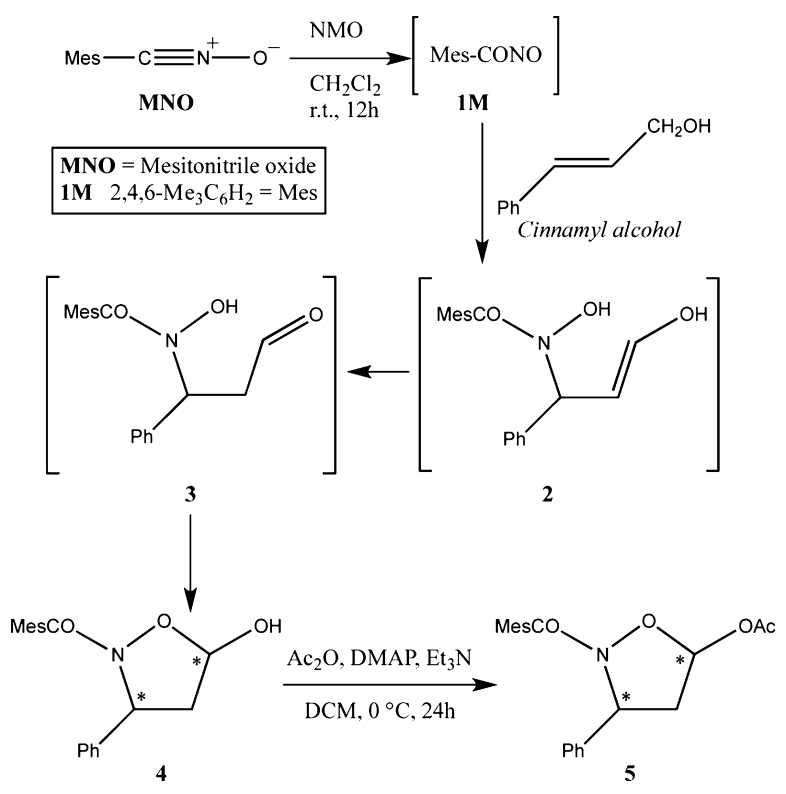

dimerization and rearrangement of the dimer of the nitrosocarbonyl mesitylene $\mathbf{1 M}$. The anhydrides are the products of the dimerization process of nitrosocarbonyls when their capture with dienes or enes is too slow, as demonstrated in previous works. ${ }^{9}$ The slow reaction rate of the ene reaction of the nitrosocarbonyl mesitylene $\mathbf{1 M}$ is also confirmed by the fair yield of the isoxazolidine 4 , obtained as a result of the ene addition and formation of the enol intermediate 2 that undergoes tautomerism to the aldehyde 3 and subsequent cyclization.

The ene adduct 4 was then acetylated according to the established procedure above reported, ${ }^{10}$ and compound $\mathbf{5}$ was obtained in $80 \%$ yield as a mixture of diastereoisomers in the same ratio (nearly 1:1) of the starting material. The structure of $\mathbf{5}$ was confirmed by the relative spectroscopic data; in the ${ }^{1} \mathrm{H}$ NMR spectrum $\left(\mathrm{CDCl}_{3}\right)$, the acetate group is clearly show 
by the singlet at $2.03 \delta$ corresponding to the methyl as well as by the presence in the infrared (IR) spectrum of the $\mathrm{C}=\mathrm{O}$ band at $1764 \mathrm{~cm}^{-1}$ and the absence of the $\mathrm{OH}$ band. The other signals are in the expected range for the given isoxazolidine structure.

The analytical and spectroscopic data of adduct 4 were consistent with its existence as an inseparable mixture of diastereoisomers. The IR spectrum shows the presence of the $\mathrm{OH}$ group with a band at $3368 \mathrm{~cm}^{-1}$. In the NMR spectra $\left(\mathrm{CDCl}_{3}\right)$, the mixture of diastereoisomers is clearly shown in the ratio $3: 1$. Focusing the attention on the major diastereoisomer, the isoxazolidine structure is confirmed by the presence in the ${ }^{1} \mathrm{H}$ NMR spectrum of the hemiacetal proton at $6.11 \delta(\mathrm{d}, J=5 \mathrm{~Hz})$ and the benzylic proton at $4.78 \delta$ $(\mathrm{t}, J=8 \mathrm{~Hz})$, coupled with the methylene found at 2.48 and $2.82 \delta(\mathrm{m}, 1 \mathrm{H}+1 \mathrm{H})$. In the ${ }^{13} \mathrm{C}$ NMR spectrum, the hemiacetal carbon atom is found at $98.3 \delta$ and the other signals in the expected range. The definitive confirmation of the structure of 4 came from the X-ray analysis, and Figure 1 reports the ORTEP view of the compound.

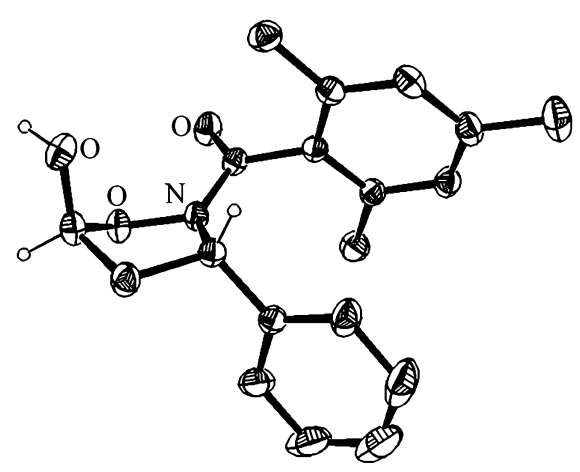

Figure 1. X-ray structure of ene adduct 4 .

We performed the functionalization of the isoxazolidine 5 with the commercially available 6-chloropurine by adapting the standard protocol for the insertion of heterobases on isoxazolidine rings. In this case, we expect to have four derivatives because the purine rings give two regioisomeric adducts at the N7 and N9 nitrogen atoms on the two diastereoisomers. ${ }^{11}$

The acetylated isoxazolidine $\mathbf{5}$ was added under nitrogen atmosphere at $\mathrm{rt}$ to a solution of 6-chloropurine (2 equiv) and bis(trimethylsilyl)acetamide (BSA) (2 equiv), and the solutions became clear after boiling in DCM for a couple of hours. The mixtures were then ice-cooled at $0{ }^{\circ} \mathrm{C}$ and trimethylsilyl trifluoromethanesulfonate (TMSO-Tf; 1 equiv) was added and the reactions refluxed overnight (Scheme 3 ).

The desired compounds $\mathbf{6 a - d}$ were obtained as white solids separated by column chromatography. The purine nucleoside analogues $\mathbf{6 a - d}$ were isolated in fair yields (range 25-35\%). On the basis of previous observations, ${ }^{5,11}$ the reaction was conducted on the mixture of the diastereoisomeric acetylated compounds 5 to give a mixture of four possible diastereoisomeric products through the stabilized intermediate (see inset in Scheme 3). In fact, the purine ring can be linked at the isoxazolidine moiety through the N7 and/or N9 nitrogen atoms. The stereochemical outcome is in full accordance with Yadav's and Woerpel's observations on the behavior of oxocarbenium ions, simply alkyl or aryl substituted. ${ }^{12}$ Table 1 reports the yields, physical-chemical data, and the relevant
Scheme 3. Synthesis of 6-Chloropurine IsoxazolidineNucleoside Analogues through Vorbrüggen Protocol

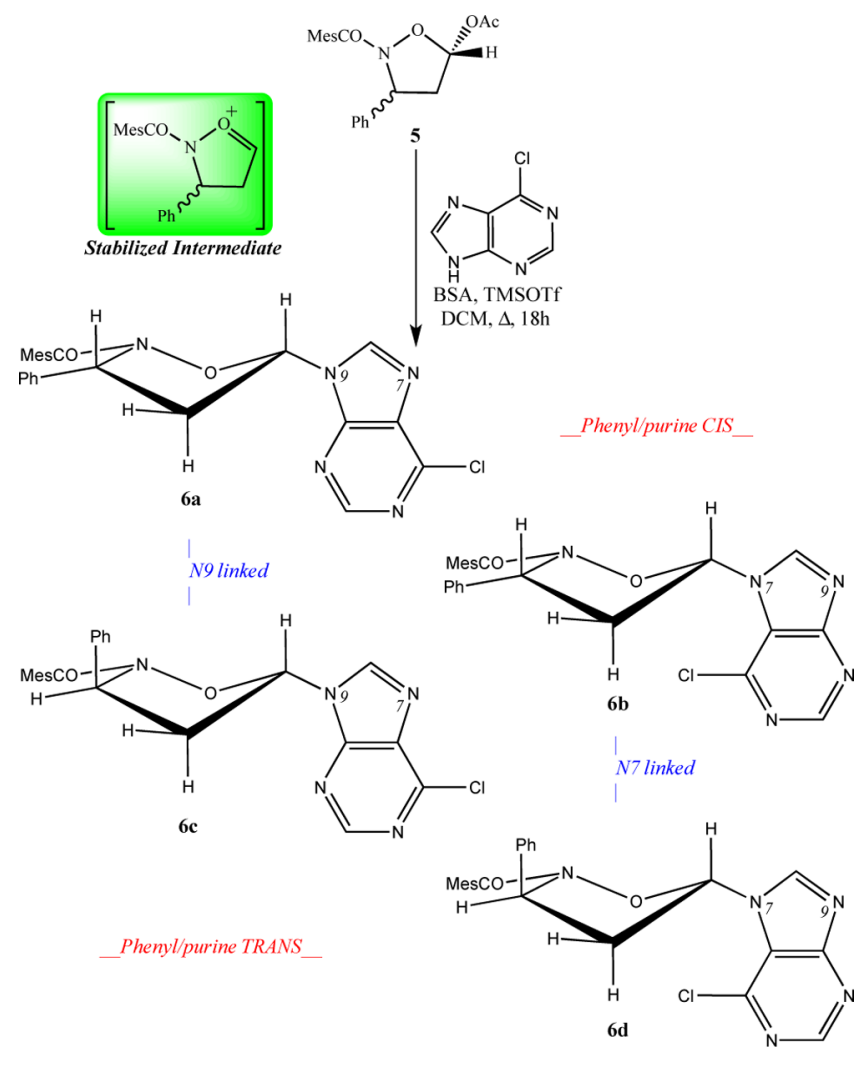

Table 1. Yields, Physical-Chemical, and Spectroscopic Data of Compounds 6a-d

\begin{tabular}{ccccc} 
& & & \multicolumn{3}{c}{$\mathrm{IR}$} \\
\cline { 4 - 5 } 6 & $\mathrm{mp}\left({ }^{\circ} \mathrm{C}\right)^{a}$ & yield $(\%)$ & $\nu_{\mathrm{C}=\mathrm{O}\left(\mathrm{cm}^{-1}\right)} \nu_{\mathrm{C}=\mathrm{N}}\left(\mathrm{cm}^{-1}\right)$ \\
A & $191-194$ & 35 & 1660 & 1625 \\
B & $198-200$ & 25 & 1659 & 1604 \\
C & $204-206$ & 27 & 1636 & 1595 \\
D & $233-236$ & 32 & 1625 & 1593 \\
& & ${ }^{1} \mathrm{H} \mathrm{NMR}(\delta$, DMSO $)$ & \\
6 & $\mathrm{CH}-\mathrm{N}$ & $\mathrm{O}-\mathrm{CH}-\mathrm{Pur}$ & $\mathrm{CH}=\mathrm{N}_{\text {imid }}$ & $\mathrm{CH}=\mathrm{N}_{\text {pyrim }}$ \\
A & $5.90(\mathrm{t})$ & $6.66(\mathrm{t})$ & $8.80(\mathrm{~s})$ & $8.71(\mathrm{~s})$ \\
B & $5.95(\mathrm{t})$ & $6.74(\mathrm{t})$ & $8.87(\mathrm{~s})$ & $8.82(\mathrm{~s})$ \\
C & $5.92(\mathrm{t})$ & $6.86(\mathrm{~d})$ & $9.35(\mathrm{~s})$ & $8.81(\mathrm{~s})$ \\
D & $6.09(\mathrm{t})$ & $6.78(\mathrm{~d})$ & $9.07(\mathrm{~s})$ & $8.71(\mathrm{~s})$
\end{tabular}

${ }^{a}$ White solids from ethanol/diisopropyl ether.

${ }^{1} \mathrm{H}$ NMR spectroscopic data supporting the structural assignments given in Scheme 3. Compounds $\mathbf{6 a}-\mathbf{d}$ were fully characterized, and their structures correctly attributed to the cis- or trans-series; these labels refer to the stereochemical relationship between the phenyl group and the purine ring located on the isoxazolidine moiety. Compounds $\mathbf{6 a}, \mathbf{b}, \mathrm{N9}$, and N7 purine-linked, belong to the cis-series; in particular, the nuclear overhauser spectroscopy (NOESY) experiment conducted on compound $\mathbf{6 b}$ allowed for the correct attribution of the cis relationship between the above-cited groups on the isoxazolidine ring, as shown by the nuclear Overhauser effect (NOE) correlation indicated by red arrows in Figure 2. Compounds $6 \mathbf{c}, \mathrm{d}, \mathrm{N} 9$ and N7 purine-linked, belong to the trans-series; in particular, the NOESY experiments performed 
$6 a$

$6 c$
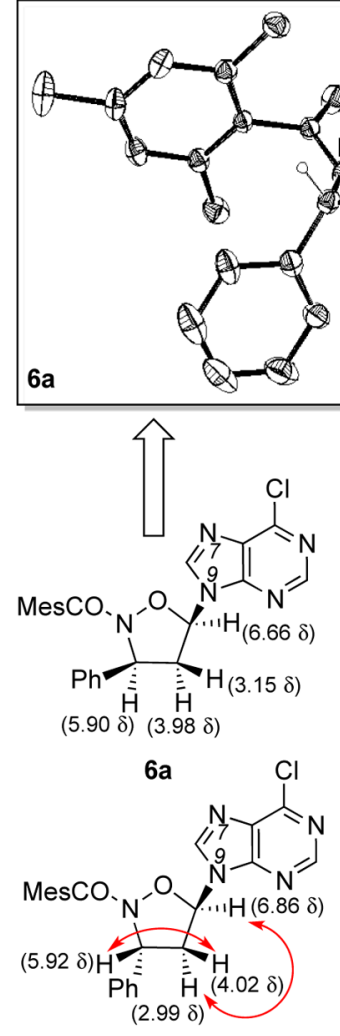

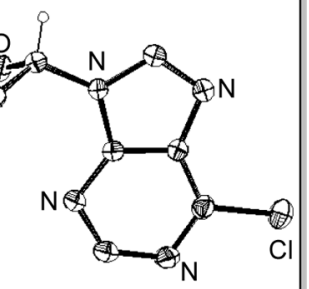

NOE Correlations

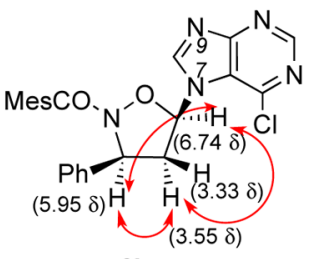

$6 b$

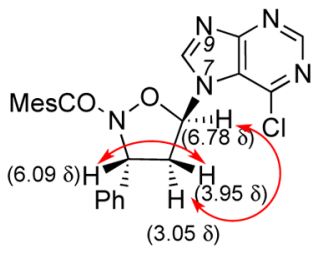

6d
Figure 2. X-ray structure of ene adduct $6 \mathrm{a}$ and NOE correlations for adducts $6 \mathbf{b}-\mathbf{d}$.

on both of the compounds gave successful results, and the structures in Figure 2 show the NOE correlations between the marked protons. The attribution of the regiochemical arrangement of the 6-chloropurine ring in the four compounds, although more intriguing, was a challenging task.

After several attempts to crystallize the four nucleoside analogues to have single crystals for X-ray structural attributions; for one of those $6 \mathrm{a}$, we managed to obtain the expected result, and the ORTEP view is shown in Figure 2. This structure and the NMR data and NOESY experiments performed on all of the compounds $6 \mathbf{a}-\mathbf{d}$ allowed collecting the needed information to attribute unambiguously the structures as reported in Scheme 3 and Figure 2.

Compounds $6 \mathrm{a}$ and $6 \mathrm{c}$ possess the purine ring attached to the isoxazolidine ring through the $\mathrm{N} 9$ nitrogen of the heterobase, whereas compounds $\mathbf{6 b}$ and $\mathbf{6 d}$ show the purine ring upside down because the attachment occurs through the N7 nitrogen atom of the heterocyclic ring. These structural features will be further considered in the discussion concerning the biological data here presented.

Samples of compounds $\mathbf{6 a}-\mathbf{d}$ were biologically assayed to assess their proapoptotic, metabolic, and cytotoxic activities. For the scope, the human monocytoid U937, and the lymphoblastoid MOLT-3 cell lines were grown in RPMI (Life Technologies, Paisley, UK) supplemented with 10\% heatinactivated fetal bovine serum (Life Technologies), $2 \mathrm{mM}$ glutamine (Hyclone, Cramlington, UK), $50 \mathrm{U} / \mathrm{mL}$ penicillin, and $50 \mathrm{U} / \mathrm{mL}$ streptomycin (HyClone), hereafter defined as CM. The metabolic inhibition was evaluated by MTS assay. The compounds were added at the range concentration from 80 to $2.5 \mu \mathrm{M}$. Inhibition of the cell metabolic activity was detected through formazan product formation, using a commercial colorimetric kit (MTS [3,4-(5-dimethylthiazol-2yl)-5-(3-carboxy methoxyphenyl)-2-(4-sulfophenyl)-2H-tetrazolium salt $]) .^{13}$

The cytotoxic assay was carried on in U937, MOLT-3 cell lines, and stimulated mononuclear cells from healthy donors (PBMC) as control, in the presence of compounds at 10, 5, and $2.5 \mu \mathrm{M}$ concentration. The evaluation of dead and living cells, respectively, was performed by using the trypan blue dye exclusion test, after $24 \mathrm{~h}$ of culture. As a drug control, it was used as a chemotherapeutic drug, etoposide, at $10 \mu \mathrm{M}$ concentration. The metabolic inhibition $\left(\mathrm{MAIC}_{50}\right)$ and cytotoxicity $\left(\mathrm{CC}_{50}\right)$ activity were expressed as concentration inhibiting $50 \%$ of the activity \pm standard deviation (SD).

Apoptosis was assessed by flow cytometry analysis of isolated nuclei after staining with propidium iodide, as previously described. ${ }^{14}$ The tested compounds $\mathbf{6 a}-\mathbf{d}$ exhibited

Table 2. Metabolic Acitivities of Compounds 6a-d

\begin{tabular}{|c|c|c|c|c|c|c|c|c|c|}
\hline \multirow[b]{2}{*}{6} & \multirow[b]{2}{*}{ Conc. $(\mu \mathrm{M})$} & \multicolumn{2}{|c|}{ hypodiploid nuclei ${ }^{a} \pm$ SD (\%) } & \multicolumn{3}{|c|}{$\mathrm{MAIC}_{50} \pm \mathrm{SD}(\mu \mathrm{M})^{b}$} & \multicolumn{3}{|c|}{$\mathrm{CC}_{50} \pm \mathrm{SD}(\mu \mathrm{M})^{c}$} \\
\hline & & U937 & MOLT-3 & U937 & MOLT-3 & PBMC & U937 & MOLT-3 & PBMC \\
\hline \multirow[t]{3}{*}{ a $N 9$ cis } & 10 & $42.0 \pm 2.0$ & $43.6 \pm 0.8$ & $5.7 \pm 0.3$ & $6 \pm 0.3$ & $3.6 \pm 0.6$ & $0.6 \pm 0.1$ & $4.1 \pm 0.2$ & $25 \pm 5.0$ \\
\hline & 5 & $35.0 \pm 1.4$ & $36.3 \pm 2.9$ & & & & & & \\
\hline & 2.5 & $33.0 \pm 1.5$ & $12.7 \pm 3.2$ & & & & & & \\
\hline \multirow[t]{3}{*}{ b $N 7 c i s$} & 10 & $27.5 \pm 3.2$ & $7.8 \pm 0.2$ & $16 \pm 1.6$ & $17 \pm 1.6$ & $35 \pm 0.9$ & $9 \pm 1.4$ & $15.6 \pm 1.5$ & $47.7 \pm 11$ \\
\hline & 5 & $12.3 \pm 2.4$ & $6.0 \pm 0.1$ & & & & & & \\
\hline & 2.5 & $6.4 \pm 0.3$ & $5.0 \pm 1.7$ & & & & & & \\
\hline \multirow[t]{3}{*}{ c N9trans } & 10 & $29.0 \pm 3.7$ & $10.5 \pm 1.6$ & $15 \pm 0.9$ & $9 \pm 0.2$ & $15.0 \pm 2.1$ & $4.5 \pm 0.7$ & $8.5 \pm 1.3$ & $57 \pm 2.0$ \\
\hline & 5 & $35.0 \pm 1.4$ & $11.2 \pm 0.3$ & & & & & & \\
\hline & 2.5 & $13.8 \pm 1.0$ & $11.2 \pm 2.7$ & & & & & & \\
\hline \multirow[t]{3}{*}{ d N7trans } & 10 & $55.6 \pm 0.1$ & $30.5 \pm 4.3$ & $5.1 \pm 0.5$ & $4.7 \pm 0.1$ & $15.4 \pm 0.6$ & $4.3 \pm 0.6$ & $6.0 \pm 0.1$ & $27 \pm 6.0$ \\
\hline & 5 & $44.0 \pm 0.1$ & $20.0 \pm 5.6$ & & & & & & \\
\hline & 2.5 & $10.7 \pm 0.3$ & $6.0 \pm 0.1$ & & & & & & \\
\hline SN38 ${ }^{d}$ & 10 & $63.6 \pm 0.01$ & $55.5 \pm 2.4$ & $6.7 \pm 0.1$ & $5.6 \pm 0.1$ & $6.9 \pm 0.2$ & $7 \pm 0.1$ & $7 \pm 0.1$ & $11.4 \pm 2.8$ \\
\hline
\end{tabular}

${ }^{a}$ Effects of the compounds in U937 and MOLT-3 cell lines. Apoptosis was evaluated as a percentage hypodiploid nuclei by flow cytometry analysis after $18 \mathrm{~h}$ of incubation. ${ }^{b} \mathrm{MAIC}_{50}$ is the metabolic activity cytotoxic inhibitory concentration $50 \%$, evaluated by MTS assay. ${ }^{c} \mathrm{CC} \mathrm{C}_{50}, \mathrm{cytotoxic}$ concentration 50, is the concentration of the compounds required to cause $50 \%$ toxicity, detected by Trypan blue test. ${ }^{d} 7$-Ethyl-10-hydroxycamptotecine. 
different abilities to induce cell death by apoptosis, to inhibit metabolic activity and cell growth (Table 2). All of the four compounds induced apoptosis, expressed as a percentage of hypodiploid nuclei, in dose effect, although $\mathbf{6 a}$ and $\mathbf{6 d}$ at higher level than $\mathbf{6 b}$ and $\mathbf{6 c}$ and close to that induced by etoposide $(63 \pm 0.01$ and $55 \pm 2.4)$. Conversely, the compounds $6 \mathbf{b}$, an N7cis compound, and 6c, an N9trans compound, hence showing opposite localizations of chlorine atom, inhibited metabolic activity of U937 and MOLT-3 cells (MAIC ${ }_{50}$ ) at higher concentration in comparison with compounds $\mathbf{6 a}$ and 6d, which showed phenyl in cis and trans, respectively, but with different match with the position of chlorine substitution (see structures in Scheme 3). This indicates that $\mathbf{6 a}$ and $\mathbf{6 d}$ show higher level of proapoptotic activity and metabolic inhibition than that of $\mathbf{6 b}$ and $\mathbf{6 c}$ toward tumor cells, respectively.

On the other side, the cytotoxicity $\left(\mathrm{CC}_{50}\right)$ toward both tumor cell lines was as follows: $6 \mathbf{a}>\mathbf{6 d}>\mathbf{6 c}>\mathbf{6 b}$, showing that the N9cis (6a) compound was more cytotoxic than that corresponding with N7cis (6b) and the compounds of the trans series located in between. Collectively, the induction of apoptosis and/or the inhibition of metabolic and cytotoxic activity of the tested compounds at $10 \mu \mathrm{M}$ were similar to that exhibited by the positive control etoposide. Assays on stimulated PBMC were carried on to investigate the metabolic and the cytotoxic inhibitory activity of the compounds versus normal cells. The results indicated that $\mathbf{6} \mathbf{b}$ was the least cytotoxic showing $\mathrm{MAIC}_{50}$ of $35 \pm 0.9 \mathrm{SD}$, whereas $\mathbf{6 c}$ and $\mathbf{6 d}$ showed $15.4 \pm 0.6$ and $15.0 \pm 2.1 \mathrm{SD}$, respectively.

Conversely, 6a showed a MAIC50 of $3.6 \pm 0.6$ SD. Anyhow, the compounds $\mathbf{6 b}, \mathbf{6 c}$, and $\mathbf{6 d}$ were low metabolic inhibitors than etoposide. Similarly, the compounds $\mathbf{6 b}$ and $\mathbf{6 c}$ exhibited lower cytotoxic activity versus stimulated PBMC than that of $\mathbf{6 a}$ and $\mathbf{6 d}$. Interestingly $\mathbf{6 b}-\mathbf{d}$ inhibited PBMC metabolism and $\mathbf{6 a - d}$ cytotoxicity at lower level, respectively, in comparison with etoposide.

Taken together, the biological assays have shown that all of the four tested compounds were endowed with antitumor activity. Nevertheless their antitumor activity cannot be ascribed exclusively to a mechanism of programmed cell death because the compounds endowed with higher proapoptotic activity also showed higher metabolic and cytotoxic activity toward tumor cells. The encouraging aspect is that the general toxicity versus healthy cells is lower than that exhibited by etoposide. In terms of SAR, it can be hypothesized that the stoichiometric structure including the substitution of chlorine atom versus nitrogen associated to phenyl group in cis and/or in trans might influence the apoptotic and metabolic activity of the compounds toward U937, MOLT-3 cells, and normal tissues.

To shed some light on a tentative SAR for the compounds at hand, we have observed the four racemic compounds $\mathbf{6 a}-\mathbf{d}$ from the conformational point of view by performing ab initio calculations by means of density functional theory methods at the B3LYP(6-31G) (d,p) level. ${ }^{15}$ Figures 3 and 4 show the gasphase-optimized conformations divided into two main sets: (1) in Figure 3, structures of the cis series of compounds $\mathbf{6 a}, \mathbf{b}$ and (2) in Figure 4, structures of the trans series of compounds $\mathbf{6 c}, \mathbf{d}$. The reported structures, the most populated according to the Boltzmann distribution, show in some cases the 6chloropurine ring in pseudo-equatorial positions and in other cases the same heterobase in pseudo-axial positions; they are

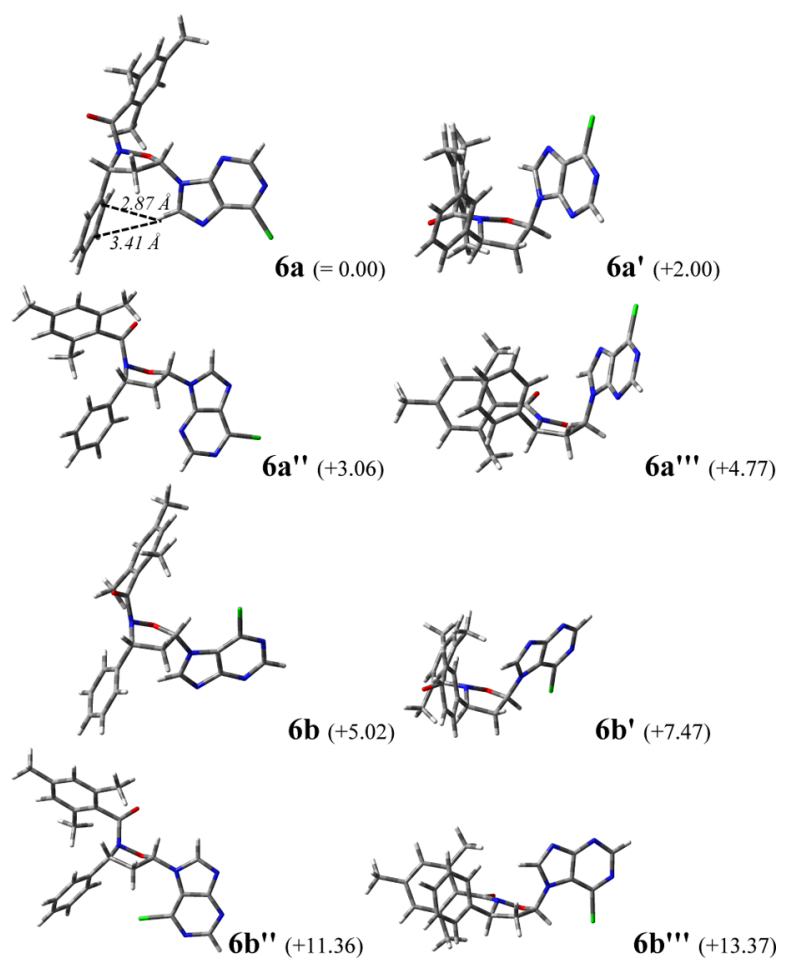

Figure 3. Derivatives of the cis series of compounds $\mathbf{6 a}, \mathbf{b}$.

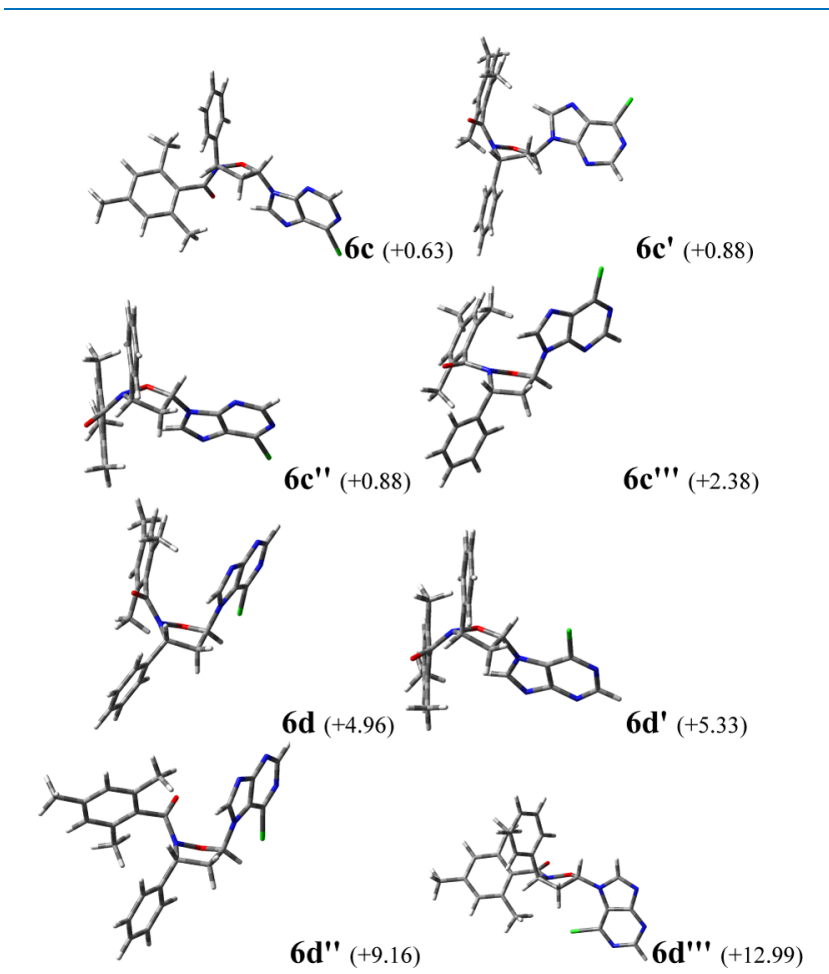

Figure 4. Derivatives of the trans series of compounds 6 c,d.

reported along with the relative energies $(\Delta E, \mathrm{kcal} / \mathrm{mol})$ relative to the most stable structure $6 \mathrm{a}(\Delta E=0.00 \mathrm{kcal} / \mathrm{mol})$.

Compound $\mathbf{6 a}$ is the most stable of all compounds and belongs to the N9 derivative series; it is reasonably stabilized by nonclassical intramolecular $\mathrm{H}$-bond between the purine $\mathrm{H}-$ $\mathrm{C}=\mathrm{N}$ proton and the phenyl ring, as shown in Figure 3, with distances in $\AA$. The other structures $\mathbf{6} \mathbf{a}^{\prime}, \mathbf{6} \mathbf{a}^{\prime \prime}$, and $\mathbf{6 a}^{\prime \prime \prime}$ were located at higher energies because they lack intramolecular 
stabilizing effects. Compound 6a shows the 6-chloropurine ring in the pseudoequatorial position. The same cis series includes the N7 derivatives: $\mathbf{6 b}$ (the most stable of the group) is $5.02 \mathrm{kcal} / \mathrm{mol}$ higher than $\mathbf{6 a}$. All of the other structures $\mathbf{6} \mathbf{b}^{\prime}$, $\mathbf{6 b}$," and $\mathbf{6} \mathbf{b}^{\prime \prime \prime}$ showed some steric destabilizing effects because of the mesityl methyls groups pointing to other parts of the molecules.

Close in energy, the N9 derivatives of the trans series show the structure $\mathbf{6 c}$ as the most stable and closest in energy to $\mathbf{6 a}$. Again, 6c shows the 6-chloropurine ring in the pseudoequatorial position. The other structures $\mathbf{6} \mathrm{c}^{\prime}, \mathbf{6} \mathrm{c}^{\prime \prime}$, and $\mathbf{6} \mathrm{c}^{\prime \prime}$ are located at higher energies up to $2 \mathrm{kcal} / \mathrm{mol}$. Similarly as before, the N7 derivatives of the trans series show higher energies with respect to the N9 ones but the most stable of them is $6 \mathrm{~d}$ that shows the 6-chloropurine ring in the pseudo-axial position; partially $\pi-\pi$ stacking interactions between the 6-chloropurine ring and the mesitoyl substituent can act as stabilizing effects.

Previously described biological data somewhat locate the four compounds $6 \mathrm{a}-\mathbf{d}$ activities into two groups of two compounds each: $\mathbf{6 a} / \mathbf{6 d}$ and $\mathbf{6 b} / \mathbf{6 c}$. Taking this into account, some of the structures reported in Figures 3 and 4 can be overlapped evidencing interesting and quite unexpected similarities between different diaestereoisomers. Figure 5

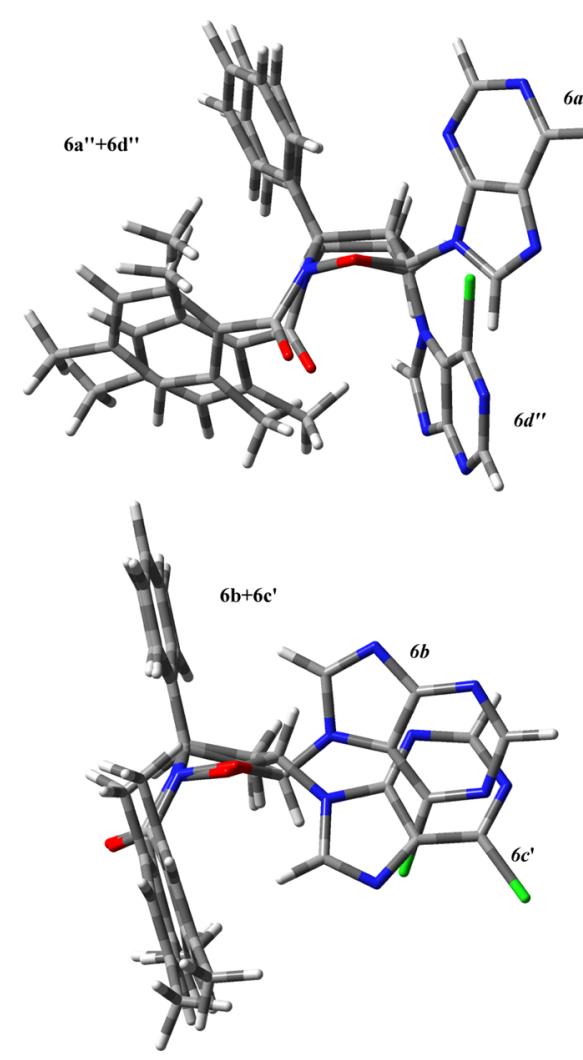

Figure 5. Overlap of the $6 a^{\prime \prime}+6 d^{\prime \prime}$ and $6 b+6 c^{\prime}$ optimized structures.

shows the best fittings between the reported optimized structures that includes $6 a^{\prime \prime}+6 d^{\prime \prime}$ and $6 b+6 c^{\prime}$. In the $6 a^{\prime \prime}$ $+6 \mathrm{~d}^{\prime \prime}$ case, the $\mathrm{N}-\mathrm{O}$ bond in the isoxazolidine ring overlaps, and a good overlap is also found for the entire heterocyclic ring. The two phenyl rings are also nicely overlapped, whereas the fitting of the two structures is less efficient for the mesitoyl group. The two 6-chloropurine rings are located in two different positions in the two compounds. In $\mathbf{6} \mathbf{a}^{\prime \prime}$, the purine ring points the chlorine atom in the outer space from an equatorial position, whereas in $6 \mathrm{~d}^{\prime \prime}$, it is found trans to the phenyl rings in the axial position, orienting the chlorine atom in nearly the same plane of the isoxazolidine ring. The locations of the 6-chloropurines strongly discriminate between the two compounds, which have indeed different activities.

In the $\mathbf{6 b}+\mathbf{6} \mathbf{c}^{\prime}$ case, the $\mathrm{N}-\mathrm{O}$ bond in the isoxazolidine ring and the entire isoxazolidine ring are totally overlapped. The fittings of both the two phenyl and the mesitoyl groups are excellent. On the other hand, the two 6-chloropurine rings are both located equatorially to the isoxazolidine ring, both pointing to the chlorine atom downward and opposite to the phenyl rings. In this case, the two structures overlap the evidence with more similarities between them.

From these observations, the main differences remain between $6 \mathbf{a}$ and $\mathbf{6 d}$ : the positions of the 6-chloropurine rings are discriminant between the two structures even when a good overlap can be found between the other parts of the molecules. Fewer differences can be found between compounds $\mathbf{6 b}$ and 6c. These statements nicely fit with the biological data and with possibility to tune the proapoptotic activity and cytotoxicity by modifying the structures at the level of the chlorine atom or alternatively at the level of the aromatic rings.

These and further modifications of the described molecules are indeed desirable to increase the antitumor effect and decrease the off-target activity. We are actively pursuing the syntheses of novel nucleoside analogues by applying the same nitrosocarbonyl chemistry.

\section{CONCLUSIONS}

In conclusion, we have investigated the ene reactions of nitrosocarbonyl mesitylene, generated through the mild oxidative protocol with NMO, with cinnamyl alcohol. The fast oxidation process of nitrile oxide to nitrosocarbonyl intermediate prevents a possible side reaction, that is, the 1,3dipolar cycloaddition. ${ }^{16}$ From the reaction mixtures, the presence of adducts between the aromatic nitrile oxide and the cinnamyl alcohol was not observed in isolable amounts, even in crude mixtures.

The nitrosocarbonyl mesitylene $\mathbf{1} \mathbf{M}$ adds the cinnamyl alcohol affording a single adduct $\mathbf{5}$ that derives from the $\mathrm{C} 3$ addition to the alcohol in the ene reaction. ${ }^{5}$

The purine functionalization of $\mathbf{5}$ proceeds as expected, furnishing four compounds $\mathbf{6 a - d}$ whose structures were attributed with the help of NMR experiments and X-ray diffractometry. The biological tests reveal that all of the four compounds induced apoptosis, expressed as percentage of hypodiploid nuclei, in dose effect, although $\mathbf{6 a}$ and $\mathbf{6 d}$ are at higher levels than $\mathbf{6 b}$ and $\mathbf{6 c}$.

The cytotoxicity toward both tumor cell lines was as follows: $\mathbf{6 a}>\mathbf{6 d}>\mathbf{6 c}>\mathbf{6 b}$, showing that the N9cis (6a) compound was more cytotoxic than that the corresponding N7cis $(\mathbf{6 b})$ and the compounds of the trans series located in between. Collectively, the induction of apoptosis and/or the inhibition of metabolic and cytotoxic activity of the tested compounds at $10 \mu \mathrm{M}$ were similar to that exhibited by the positive control etoposide.

In terms of SAR, it can be hypothesized that the stoichiometric structure including the substitution of chlorine atom versus nitrogen associated with the phenyl group in cis and/or in trans might influence the apoptotic and metabolic activity of the compounds toward U937, MOLT-3 cells, and normal tissues. 


\section{EXPERIMENTAL SECTION}

All of the melting points (mp) are uncorrected. Elemental analyses were done on an elemental analyzer available at the Department. ${ }^{1} \mathrm{H}$ and ${ }^{13} \mathrm{C}$ NMR spectra were recorded on a 300 $\mathrm{MHz}$ spectrometer (solvents specified). Chemical shifts are expressed in parts per million from internal tetramethylsilane $(\delta)$, and coupling constants $(J)$ are in hertz $(\mathrm{Hz}): \mathrm{b}$, broad; s, singlet; bs, broad singlet; $d$, doublet; $t$, triplet; qi, quintet; and $\mathrm{m}$, multiplet. IR spectra (nujol mulls) were recorded on a spectrophotometer available at the Department and absorptions $(\nu)$ are in - centimeter-squared. Column chromatography and tlc: silica gel $\mathrm{H} 60$ and $\mathrm{GF}_{254}$, respectively; eluants: cyclohexane/ethyl acetate 9:1 to pure ethyl acetate; when specified, pure $\mathrm{CHCl}_{3}$ to $\mathrm{CHCl}_{3} / \mathrm{MeOH} 9 / 1$ for the nucleosides syntheses.

Starting and Reference Materials. Cinnamyl alcohol (98\%) was purchased from the chemical supplier.

MNO was obtained by oxidation of 2,4,6-trimethylbenzaldoxime with bromine. ${ }^{16 \mathrm{~b}}$

Other reagents and solvents were purchased from chemical suppliers and used without any further purification.

Ene Reaction of Nitrosocarbonyl Mesitylene $1 \mathrm{M}$ with Cinnamyl Alcohol. To an ice-cooled DCM (200 mL) solution of cinnamyl alcohol ( $32 \mathrm{~mL}, 5$ equiv), $8.73 \mathrm{~g}$ (1.5 equiv) of $\mathrm{NMO}$ was added under stirring. A solution of $8.01 \mathrm{~g}$ (50 mmol) of MNO in $200 \mathrm{~mL}$ of DCM was added dropwise, and the reaction was left under stirring at rt for $24 \mathrm{~h}$. After dilution with an equivalent volume of DCM, the organic phase was washed with water and dried over anhydrous $\mathrm{Na}_{2} \mathrm{SO}_{4}$. After filtration, the solvent was then evaporated, and the reaction mixture separated on column chromatography, affording the ene adduct 4 as an inseparable mixture of diastereoisomers in the ratio 3:1. In the NMR spectra of 4, the signals of the minor diastereoisomer are reported in brackets.

4 (5.92 g, 38\%) white crystals from ethanol, mp 179-181 ${ }^{\circ} \mathrm{C}$. IR: $\nu_{\mathrm{OH}} 3386, \nu_{\mathrm{C}=\mathrm{O}} 1639 \mathrm{~cm}^{-1} .{ }^{1} \mathrm{H}$ NMR $\left(\mathrm{CDCl}_{3}\right): \delta$ 1.56, 2.26, and $2.46\left(\mathrm{~s}, 9 \mathrm{H}, \mathrm{CH}_{3}\right), 2.48$ and $2.82(\mathrm{~m}, 1 \mathrm{H}+1 \mathrm{H}$, $\left.\mathrm{CH}_{2}\right), 4.78$ [5.77] $(\mathrm{t}, 1 \mathrm{H}, \mathrm{J}=8 \mathrm{~Hz}, \mathrm{~N}-\mathrm{CH}), 6.11$ [5.65] (d, $1 \mathrm{H}, J=5 \mathrm{~Hz}, \mathrm{O}-\mathrm{CH}-\mathrm{O}$ ), $6.53(\mathrm{~s}, 1 \mathrm{H}, \mathrm{OH}), 6.88$ (group of singlets for both diast., $\mathrm{Ph}$ ), 7.17-7.45 ( $\mathrm{m}$ for both diast., $\mathrm{Ph}$ ). ${ }^{13} \mathrm{C} \mathrm{NMR}\left(\mathrm{CDCl}_{3}\right): \delta 18.1,19.2$, [19.5], 21.0, 45.7 [45.0], 61.1 [58.1], 98.3 [97.6], 126.5 [125.9], 127.7 [127.4], 128.0 [128.3], 128.7, 133.8 [131.5], 135.5 [134.8], 138.7 [138.4], 140.4 [140.9], 168.3 [170.2]. Anal. Calcd for $\mathrm{C}_{19} \mathrm{H}_{21} \mathrm{NO}_{3}$ (311.37): C, 73.29; H, 6.80; N, 4.50. Found: C, 73.26; H, 6.81; $\mathrm{N}, 4.54$.

Synthesis of the $\mathrm{N}$-Mesitoyl-3-phenyl-5-acetoxy-1,2isoxazolidine 5. To an ice-cooled anhydrous DCM (150 $\mathrm{mL}$ ) solution of $\mathrm{N}$-mesitoyl-3-methyl-5-hydroxy-1,2-isoxazolidine $4(1.00 \mathrm{~g}, 12.4 \mathrm{mmol}), 2.2$ equiv of $\mathrm{Ac}_{2} \mathrm{O}$ were added under stirring along with 0.2 equiv of DMAP and 2.2 equiv of $\mathrm{Et}_{3} \mathrm{~N}$. The reaction is left under stirring at $\mathrm{rt}$ for $24 \mathrm{~h}$. After dilution with an equivalent volume of DCM, the organic phase was washed with a saturated solution of $\mathrm{NaHCO}_{3}$ and dried over anhydrous $\mathrm{Na}_{2} \mathrm{SO}_{4}$. After filtration, the solvent was evaporated and an oily residue is obtained corresponding to the inseparable mixture of the two diastereoisomers 5, purified by column chromatography and fully characterized. In the NMR spectra of $\mathbf{5}$, the signals of the minor diastereoisomer are reported in brackets.

5 (3.51 g, 80\%) white crystals from ethanol, mp 120-122 ${ }^{\circ} \mathrm{C}$. IR: $\nu_{\mathrm{C}=\mathrm{O}} 1764,1645 \mathrm{~cm}^{-1} \cdot{ }^{1} \mathrm{H}$ NMR $\left(\mathrm{CDCl}_{3}\right): \delta 2.03$
[2.16] (s, 3H, $\left.\mathrm{CH}_{3} \mathrm{CO}\right), 2.29$, and 2.34 [1.36, 2.26 and 2.41] $\left(\mathrm{s}, 9 \mathrm{H}, \mathrm{CH}_{3}\right), 2.68$ and $2.94\left(\mathrm{~m}, 1 \mathrm{H}+1 \mathrm{H}, \mathrm{CH}_{2}\right), 5.71[4.75]$ $(\mathrm{t}, 1 \mathrm{H}, \mathrm{J}=8 \mathrm{~Hz}, \mathrm{~N}-\mathrm{CH}), 6.42[6.77](\mathrm{d}, 1 \mathrm{H}, \mathrm{J}=5 \mathrm{~Hz}, \mathrm{O}-$ $\mathrm{CH}-\mathrm{O}$ ), 6.85 (group of singlets for both diast., $\mathrm{Ph}$ ), 7.217.45 (m, both diast., $\mathrm{Ph}) .{ }^{13} \mathrm{C} \mathrm{NMR}\left(\mathrm{CDCl}_{3}\right): \delta 19.4$ [18.4], 19.7 [19.1], 20.9, 21.0 [21.1], 44.2 [44.7], 57.7 [60.3] 96.0 [95.7], 125.9, $126.3,127.4[127.9], 128.2$ [128.0], 128.4 $[131.5], 128.5[131.6], 128.9[133.1], 134.0,134.9[135.8]$ 138.7, [138.9] [139.9] 140.4, 169.0 [167.6], 170.4 [169.3]. Anal. Calcd for $\mathrm{C}_{21} \mathrm{H}_{23} \mathrm{NO}_{4}$ (353.41): C, 71.37; H, 6.56; N, 3.96. Found: C, 71.36; H, 6.55; N, 3.94.

Synthesis of Nucleosides $6 a-d$ by Coupling of Isoxazolidine 5 and 6-Chloropurine. A solution of 2 equiv of 6-chloropurine $(0.32 \mathrm{~g}, 2.06 \mathrm{mmol})$ and 2 equiv of BSA in anhydrous DCM $(20 \mathrm{~mL})$ is refluxed under nitrogen atmosphere for $1 \mathrm{~h}$. An additional equivalent of BSA is added, and the mixture is refluxed until it becomes clear and hence cooled to ambient temperature. A solution in DCM $(10 \mathrm{~mL})$ of isoxazolidine $5(0.37 \mathrm{~g}, 1.04 \mathrm{mmol})$ is added dropwise and cooled to $0{ }^{\circ} \mathrm{C}$ along with an addition of $0.20 \mathrm{~mL}$ ( 1 equiv) of TMSO-Tf. The reaction is refluxed under stirring overnight and finally quenched with a saturated solution of $\mathrm{NaHCO}_{3}$ at $\mathrm{pH}=7$. The mixture is diluted with an equivalent volume of DCM and washed with water and finally dried over $\mathrm{Na}_{2} \mathrm{SO}_{4}$. From the residues, nucleosides $\mathbf{6 a}-\mathbf{d}$ are isolated through column chromatography (chloroform and chloroform/methanol were used as eluants) and fully characterized.

6a $(0.16 \mathrm{~g}, 35 \%)$ white solid from ethanol, $\mathrm{mp} 191-194{ }^{\circ} \mathrm{C}$. IR: $\nu_{\mathrm{C}=\mathrm{O}} 1660, \nu_{\mathrm{C}=\mathrm{N}} 1625 \mathrm{~cm}^{-1} .{ }^{1} \mathrm{H}$ NMR (DMSO): $\delta 2.14$, 2.19, and $2.36(\mathrm{~s}, 9 \mathrm{H}, \mathrm{CH} 3), 3.15$ and $3.98(\mathrm{~m}, 1 \mathrm{H}+1 \mathrm{H}$, $\left.\mathrm{CH}_{2}\right), 5.90(\mathrm{t}, 1 \mathrm{H}, J=8 \mathrm{~Hz}, \mathrm{CH}-\mathrm{N}), 6.66(\mathrm{t}, 1 \mathrm{H}, J=7 \mathrm{~Hz}$, $\mathrm{O}-\mathrm{CH}-\mathrm{N}), 6.80$ and $6.89(\mathrm{~s}, 2 \mathrm{H}, \mathrm{Ph}), 7.51(\mathrm{~m}, 5 \mathrm{H}, \mathrm{Ph}), 8.71$ $(\mathrm{s}, 1 \mathrm{H}, \mathrm{CH}=\mathrm{N}), 8.80(\mathrm{~s}, 1 \mathrm{H} . \mathrm{CH}=\mathrm{N}) .{ }^{13} \mathrm{C}$ NMR (DMSO): $\delta 18.7,19.1,20.6,59.7,84.3,126.1,126.3,127.6,127.8,128.6$, $128.8,131.3,133.0,137.9,140.1,141.1,145.4,149.6,152.1$, 166.6, 169.1. Anal. Calcd for $\mathrm{C}_{24} \mathrm{H}_{22} \mathrm{~N}_{5} \mathrm{O}_{2} \mathrm{Cl}$ (447.92): C, 64.35; H, 4.95; N, 7.92. Found: C, 64.33; H, 4.93; N, 7.95.

6b $(0.12 \mathrm{~g}, 25 \%)$ white solid from ethanol, $\mathrm{mp} 198-200{ }^{\circ} \mathrm{C}$. IR: $\nu_{\mathrm{C}=\mathrm{O}} 1659, \nu_{\mathrm{C}=\mathrm{N}} 1604 \mathrm{~cm}^{-1} .{ }^{1} \mathrm{H}$ NMR (DMSO): $\delta 2.18$, 2.23, and $2.31\left(\mathrm{~s}, 9 \mathrm{H}, \mathrm{CH}_{3}\right), 3.33$ and $3.55(\mathrm{~m}, 1 \mathrm{H}+1 \mathrm{H}$, $\left.\mathrm{CH}_{2}\right), 5.95(\mathrm{t}, 1 \mathrm{H}, J=7 \mathrm{~Hz}, \mathrm{CH}-\mathrm{N}), 6.74(\mathrm{t}, 1 \mathrm{H}, J=6 \mathrm{~Hz}$, $\mathrm{O}-\mathrm{CH}-\mathrm{N}), 6.83$ and $6.92(\mathrm{~s}, 2 \mathrm{H}, \mathrm{Ph}), 7.40(\mathrm{~m}, 5 \mathrm{H}, \mathrm{Ph}), 8.82$ $(\mathrm{s}, 1 \mathrm{H}, \mathrm{CH}=\mathrm{N}), 8.87(\mathrm{~s}, 1 \mathrm{H} . \mathrm{CH}=\mathrm{N}) \cdot{ }^{13} \mathrm{C}$ NMR (DMSO): $\delta 18.9,19.3,20.7,59.6,85.3,122.1,126.0,127.6,127.8,128.7$, $132.3,133.7,133.9,138.1,140.2,142.6,148.1,152.4,161.9$, 170.1. Anal. Calcd for $\mathrm{C}_{24} \mathrm{H}_{22} \mathrm{~N}_{5} \mathrm{O}_{2} \mathrm{Cl}$ (447.92): C, 64.35; $\mathrm{H}$, 4.95; N, 7.92. Found: C, 64.39; H, 4.95; N, 7.95.

6c $(0.13 \mathrm{~g}, 27 \%)$ white solid from ethanol, $\mathrm{mp} 204-206{ }^{\circ} \mathrm{C}$. IR: $\nu_{\mathrm{C}}={ }_{\mathrm{O}} 1636, \nu_{\mathrm{C}}={ }_{\mathrm{N}} 1595 \mathrm{~cm}^{-1} .{ }^{1} \mathrm{H}$ NMR (DMSO): $\delta 1.03$, 2.10, and $2.26\left(\mathrm{~s}, 9 \mathrm{H}, \mathrm{CH}_{3}\right), 2.99$ and $4.02(\mathrm{~m}, 1 \mathrm{H}+1 \mathrm{H}$, $\left.\mathrm{CH}_{2}\right), 5.92(\mathrm{t}, 1 \mathrm{H}, J=8 \mathrm{~Hz}, \mathrm{CH}-\mathrm{N}), 6.86(\mathrm{~d}, 1 \mathrm{H}, J=6 \mathrm{~Hz}$, $\mathrm{O}-\mathrm{CH}-\mathrm{N}), 6.06$ and $6.76(\mathrm{~s}, 2 \mathrm{H}, \mathrm{Ph}), 7.48(\mathrm{~m}, 5 \mathrm{H}, \mathrm{Ph}), 8.81$ $(\mathrm{s}, 1 \mathrm{H}, \mathrm{CH}=\mathrm{N}), 9.35(\mathrm{~s}, 1 \mathrm{H} . \mathrm{CH}=\mathrm{N}) .{ }^{13} \mathrm{C}$ NMR (DMSO): $\delta 18.3,19.5,20.6,58.7,85.4,122.1,125.9,126.7,127.7,128.4$, $128.9,130.0,133.3,134.8,138.0,141.2,143.0,147.7,152.1$, 162.3, 168.5. Anal. Calcd for $\mathrm{C}_{24} \mathrm{H}_{22} \mathrm{~N}_{5} \mathrm{O}_{2} \mathrm{Cl}$ (447.92): C, 64.35; H, 4.95; N, 7.92. Found: C, 64.33; H, 4.97; N, 7.93.

6d $(0.15 \mathrm{~g}, 32 \%)$ white solid from ethanol, $\mathrm{mp} 233-236{ }^{\circ} \mathrm{C}$. IR: $\nu_{\mathrm{C}=\mathrm{O}} 1625, \nu_{\mathrm{C}=\mathrm{N}} 1593 \mathrm{~cm}^{-1} .{ }^{1} \mathrm{H}$ NMR (DMSO): $\delta 1.09$, 2.10, and $2.12\left(\mathrm{~s}, 9 \mathrm{H}, \mathrm{CH}_{3}\right), 3.05$ and $3.95(\mathrm{~m}, 1 \mathrm{H}+1 \mathrm{H}$, $\left.\mathrm{CH}_{2}\right), 6.09(\mathrm{t}, 1 \mathrm{H}, J=8 \mathrm{~Hz}, \mathrm{CH}-\mathrm{N}), 6.78(\mathrm{~d}, 1 \mathrm{H}, J=7 \mathrm{~Hz}$, $\mathrm{O}-\mathrm{CH}-\mathrm{N}), 6.33$ and $6.74(\mathrm{~s}, 2 \mathrm{H}, \mathrm{Ph}), 7.63(\mathrm{~m}, 5 \mathrm{H}, \mathrm{Ph}), 8.71$ $(\mathrm{s}, 1 \mathrm{H}, \mathrm{CH}=\mathrm{N}), 9.07(\mathrm{~s}, 1 \mathrm{H} . \mathrm{CH}=\mathrm{N}) \cdot{ }^{13} \mathrm{C}$ NMR (DMSO): 
$\delta 17.6,19.0,20.5,58.4,84.0,126.3,127.2,127.8,128.8,131.0$, 133.0, 134.3, 137.8, 141.1, 145.9, 149.4, 151.7, 152.0, 166.6 . Anal. Calcd for $\mathrm{C}_{24} \mathrm{H}_{22} \mathrm{~N}_{5} \mathrm{O}_{2} \mathrm{Cl}$ (447.92): C, 64.35; H, 4.95; N, 7.92. Found: C, 64.34; H, 4.96; N, 7.94.

\section{ASSOCIATED CONTENT}

\section{S Supporting Information}

The Supporting Information is available free of charge on the ACS Publications website at DOI: 10.1021/acsomega.8b00970.

${ }^{1} \mathrm{H},{ }^{13} \mathrm{C}$, and NOESY NMR spectra of reported compounds; crystallographic data and structural discussion of compounds 4 (CCDC 964613) and 6a (CCDC 971349); and Cartesian coordinates of optimized structures of compounds $\mathbf{6 a}-\mathbf{d}$ (PDF)

\section{AUTHOR INFORMATION}

\section{Corresponding Author}

*E-mail: paolo.quadrelli@unipv.it (P.Q.).

\section{ORCID}

Paolo Quadrelli: 0000-0001-5369-9140

\section{Author Contributions}

The manuscript was written through contributions of all authors. All authors have given approval to the final version of the manuscript. The authors contributed equally.

\section{Notes}

The authors declare no competing financial interest.

\section{ACKNOWLEDGMENTS}

Financial support by the University of Pavia, MIUR, (PRIN 2011, CUP: B11J12002450001) is gratefully acknowledged. The authors gratefully acknowledge the financial support of the agreement between the INSTM and Lombardy Region (2015) through the project CATSTER. The authors also thank the "VIPCAT-Value Added Innovative Protocols for Catalytic Transformations" project (CUP: E46D17000110009) for their valuable financial support.

\section{ABBREVIATIONS}

MNO, mesitonitrile oxide; NMO, $\mathrm{N}$-methylmorpholine $\mathrm{N}$ oxide; FBS, fetal bovine serum; TLC, thin-layer chromatography; SAR, structure-activity relationship

\section{REFERENCES}

(1) (a) De Clercq, E. New anti-HIV agents and targets. Med. Res. Rev. 2002, 22, 531-565. (b) Merino, P.; Anoro, S.; Franco, S.; Merchan, F. L.; Tejero, T.; Tuñon, V. J. Org. Chem. 2000, 65, 15901596.

(2) (a) Jones, R. C. F. Synthetic Applications of 1,3-Dipolar Cycloaddition Chemistry Toward Heterocycles and Natural Products; Padwa, A., Pearson, W. H., Eds.; Wiley: New York, 2002; Vol. 59, pp 1-82. (b) Morrison, J. D. Asymmetric Synthesis; Academic Press: New York, 1983; Vol. 1. (c) Mulzer, J.; Altenbach, H.-J.; Brauun, M.; Krohn, K.; Reissing, H.-U. Organic Synthesis Highlights; VCH: New York, 1991; p 77. (d) Padwa, A. Comprehensive Organic Synthesis; Trost, B. M., Fleming, I., Eds.; Pergamon: Oxford, 1991; Vol. 4, p 1069.

(3) Bortolini, O.; De Nino, A.; Eliseo, T.; Gavioli, R.; Maiuolo, L.; Russo, B.; Sforza, F. Bioorg. Med. Chem. 2010, 18, 6970-6976.

(4) (a) Chiacchio, U.; Corsaro, A.; Giofrè, S.; Romeo, G. Isoxazolidinyl Nucleosides. In Chemical Synthesis of Nucleoside Analogues; Merino, P., Ed.; Wiley, J. \& Sons, Inc.: Hoboken (NJ), 2013. (b) Romeo, R.; Giofrè, S. V.; Carnovale, C.; Chiacchio, M. A.;
Campisi, A.; Mancuso, R.; Cirmi, S.; Navarra, M. Eur. J. Org. Chem. 2014, 5442-5447. (c) Romeo, R.; Navarra, M.; Giofrè, S. V.; Carnovale, C.; Cirmi, S.; Lanza, G.; Chiacchio, M. A. Bioorg. Med. Chem. 2014, 22, 3379-3385. (d) Romeo, R.; Carnovale, C.; Giofrè, S.; Monciino, G.; Chiacchio, M.; Sanfilippo, C.; Macchi, B. Molecules 2014, 19, 14406-14416. (e) Romeo, R.; Giofrè, S. V.; Carnovale, C.; Campisi, A.; Parenti, R.; Bandini, L.; Chiacchio, M. A. Bioorg. Med. Chem. 2013, 21, 7929-7937. (f) Iannazzo, D.; Brunaccini, E.; Giofrè, S. V.; Piperno, A.; Romeo, G.; Ronsisvalle, S.; Chiacchio, M. A.; Lanza, G.; Chiacchio, U. Eur. J. Org. Chem. 2010, 5897-5905. (g) Romeo, R.; Carnovale, C.; Giofrè, S. V.; Romeo, G.; Macchi, B.; Frezza, C.; Marino-Merlo, F.; Pistarà, V.; Chiacchio, U. Bioorg. Med. Chem. 2012, 20, 3652-3657. (h) Romeo, R.; Giofrè, S. V.; Iaria, D.; Sciortino, M. T.; Ronsisvalle, S.; Chiacchio, M. A.; Scala, A. Eur. J. Org. Chem. 2011, 5690-5695.

(5) (a) Quadrelli, P.; Mella, M.; Carosso, S.; Bovio, B. J. Org. Chem. 2013, 78, 516-526. (b) Baidya, M.; Yamamoto, H. Synthesis 2013, 45, 1931-1938. (c) Carosso, S.; Memeo, M. G.; Bovio, B.; Valletta, E.; Macchi, B.; Quadrelli, P. Synthesis 2017, 49, 1972-1982.

(6) (a) Quadrelli, P.; Gamba Invernizzi, A.; Caramella, P. Tetrahedron Lett. 1996, 37, 1909-1912. (b) Quadrelli, P.; Mella, M.; Gamba Invernizzi, A.; Caramella, P. Tetrahedron 1999, 55, 10497-10510. For a comprehensive review on nitrosocarbonyls see: Memeo, M. G.; Quadrelli, P. Chem. Rev. 2017, 117, 2208-2200.

(7) (a) Quadrelli, P.; Mella, M.; Piccanello, A.; Romano, S.; Caramella, P. J. Org. Chem. 2007, 72, 1807-1810. (b) Quadrelli, P.; Romano, S.; Piccanello, A.; Caramella, P. J. Org. Chem. 2009, 74, 2301-2310. (c) Adam, W.; Krebs, O. Chem. Rev. 2003, 103, 41314146.

(8) (a) Vorbrüggen, H.; Krolikiewicz, K.; Bennua-Skalmowski, B. U.S. Patent 5,750,676, 1998. (b) Vorbrüggen, H.; Krolikiewicz, K.; Bennua, B. Chem. Ber. 1981, 114, 1234-1255. (c) Vorbrüggen, H.; Höfle, G. Chem. Ber. 1981, 114, 1256-1268. (d) Vorbrüggen, H.; Bennua, B. Chem. Ber. 1981, 114, 1279-1286. (e) For a survey on the nucleoside synthesis see: Vorbrüggen, H.; Ruh-Pohlenz, C. Handbook of Nucleoside Synthesis; Wiley, J. \& Sons: New York, 2001.

(9) (a) Quadrelli, P.; Campari, G.; Mella, M.; Caramella, P. Tetrahedron Lett. 2000, 41, 2019-2022. (b) Quadrelli, P.; Mella, M.; Caramella, P. Tetrahedron Lett. 1998, 39, 3233-3236.

(10) For acetylation of 5-hydroxy-isoxazolidines see: (a) Xiang, Y.; Gong, Y.; Zhao, K. Tetrahedron Lett. 1996, 37, 4877-4880. (b) Zhang, X.; Qing, F.-L.; Yu, Y. J. Org. Chem. 2000, 65, 70757082. (c) Zhang, X.; Xia, H.; Dong, X.; Jin, J.; Meng, W.-D.; Qing, F.L. J. Org. Chem. 2003, 68, 9026-9033.

(11) Quadrelli, P.; Mella, M.; Carosso, S.; Bovio, B. Synthesis 2013 $45,1414-1420$.

(12) Yadav, J. S.; Subba Reddy, B. V.; Srinivas Reddy, A.; Suresh Reddy, C.; Satyanarayana Raju, S. Tetrahedron Lett. 2009, 50, 66316634. (b) Larsen, C. H.; Ridgway, B. H.; Shaw, J. T.; Smith, D. M.; Woerpel, K. A. J. Am. Chem. Soc. 2005, 127, 10879-10884.

(13) Berridge, M.; Tan, A.; McCoy, K.; Wang, R. Biochemica; University of Oulu, 1996; Vol. 4, pp 14-19.

(14) Matteucci, C.; Minutolo, A.; Marino-Merlo, F.; Grelli, S.; Frezza, C.; Mastino, A.; Macchi, B. Life Sci. 2015, 127, 90-97.

(15) Frisch, M. J.; Trucks, G. W.; Schlegel, H. B.; Scuseria, G. E.; Robb, M. A.; Cheeseman, J. R.; Scalmani, G.; Barone, V.; Mennucci, B.; Petersson, G. A.; Nakatsuji, H.; Caricato, M.; Li, X.; Hratchian, H. P.; Izmaylov, A. F.; Bloino, J.; Zheng, G.; Sonnenberg, J. L.; Hada, M.; Ehara, M.; Toyota, K.; Fukuda, R.; Hasegawa, J.; Ishida, M.; Nakajima, T.; Honda, Y.; Kitao, O.; Nakai, H.; Vreven, T.; Montgomery, J. A., Jr.; Peralta, J. E.; Ogliaro, F.; Bearpark, M.; Heyd, J. J.; Brothers, E.; Kudin, K. N.; Staroverov, V. N.; Kobayashi, R.; Normand, J.; Raghavachari, K.; Rendell, A.; Burant, J. C.; Iyengar, S. S.; Tomasi, J.; Cossi, M.; Rega, N.; Millam, J. M.; Klene, M.; Knox, J. E.; Cross, J. B.; Bakken, V.; Adamo, C.; Jaramillo, J.; Gomperts, R.; Stratmann, R. E.; Yazyev, O.; Austin, A. J.; Cammi, R.; Pomelli, C.; Ochterski, J. W.; Martin, R. L.; Morokuma, K.; Zakrzewski, V. G.; Voth, G. A.; Salvador, P.; Dannenberg, J. J.; Dapprich, S.; Daniels, A. 
D.; Farkas, Ö.; Foresman, J. B.; Ortiz, J. V.; Cioslowski, J.; Fox, D. J. Gaussian 09, Revision E.01; Gaussian, Inc.: Wallingford CT, 2009.

(16) (a) Caramella, P.; Grünager, P. 1,3-Dipolar Cycloaddition Chemistry; Padwa, A., Ed.; Wiley, J. \& Sons: New York, 1984; Vol. 1, pp 291-392 and references therein. (b) Grundmann, C.; Grünanger, P. The Nitrile Oxide; Springer-Verlag: Heidelberg, 1971. (c) Grundmann, C.; Dean, J. M. J. Org. Chem. 1965, 30, 2809-2812. 